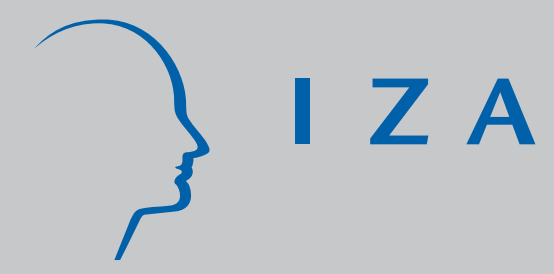

IZADP No. 2178

Imports as Product and Labor Market Discipline

Hervé Boul hol

Sabien Dobbelaere

Sara Maioli

J une 2006 


\title{
Imports as Product and Labor Market Discipline
}

\author{
Hervé Boulhol \\ IXIS-CIB and CES, \\ University Paris I Panthéon-Sorbonne
}

Sabien Dobbelaere

Ghent University, LICOS K.U. Leuven

and IZA Bonn

Sara Maioli

GEP, University of Nottingham

\section{Discussion Paper No. 2178 \\ June 2006}

IZA

P.O. Box 7240

53072 Bonn

Germany

\author{
Phone: +49-228-3894-0 \\ Fax: +49-228-3894-180 \\ Email: iza@iza.org
}

\begin{abstract}
Any opinions expressed here are those of the author(s) and not those of the institute. Research disseminated by IZA may include views on policy, but the institute itself takes no institutional policy positions.

The Institute for the Study of Labor (IZA) in Bonn is a local and virtual international research center and a place of communication between science, politics and business. IZA is an independent nonprofit company supported by Deutsche Post World Net. The center is associated with the University of Bonn and offers a stimulating research environment through its research networks, research support, and visitors and doctoral programs. IZA engages in (i) original and internationally competitive research in all fields of labor economics, (ii) development of policy concepts, and (iii) dissemination of research results and concepts to the interested public.
\end{abstract}

IZA Discussion Papers often represent preliminary work and are circulated to encourage discussion. Citation of such a paper should account for its provisional character. A revised version may be available directly from the author. 
IZA Discussion Paper No. 2178

June 2006

\section{ABSTRACT}

\section{Imports as Product and Labor Market Discipline*}

This paper tests the pro-competitive effect of trade in the product and labor markets of UK manufacturing sectors between 1988 and 2003 using a two-stage estimation procedure. In the first stage, we use data on 9820 firms from twenty manufacturing sectors to simultaneously estimate mark-up and workers' bargaining power parameters according to sector, firm size and period. We find a significant drop in both the mark-up and the workers' bargaining power in the mid-nineties. In the second stage, we relate our parameters of interest to trade variables. Our results show that imports from developed countries have significantly contributed to the decrease in both mark-ups and workers' bargaining power.

JEL Classification: $\quad$ C23, F16, J51, L13

Keywords: $\quad$ workers' bargaining power, mark-ups, pro-competitive effect

Corresponding author:

Sabien Dobbelaere

SHERPPA

Faculty of Economics and Business Administration

Ghent University

Hoveniersberg 24

9000 Gent

Belgium

Email: sabien.dobbelaere@UGent.be

\footnotetext{
* We are grateful to Daniel Mirza (Université de Rennes 1) and Giuseppe Nicoletti (OECD) for helpful comments.
} 


\section{Introduction}

Following Levinsohn's 1993 (JIE) article, many studies have drawn on Hall's (1988) approach to estimate price-marginal cost mark-ups and have provided support for the imports-as-market-discipline hypothesis, i.e. the negative impact of foreign competition on mark-ups (see Harrison, 1994; Krishna and Mitra, 1998; Konings et al., 2001; Kee and Hoekman, 2003 among others). Focusing on the labor side and inspired by Rodrik's (1997) argument that increased international trade has weakened the position of the workers, only two studies (Brock and Dobbelaere, 2006 and Dumont et al., 2006) have investigated whether stronger import competition has squeezed workers' bargaining power. The main purpose of the present contribution is to provide evidence of international competition curtailing domestic market power in the product market as well as in the labor market for UK manufacturing sectors.

Graph 1 displays the evolution in price-cost margins at the UK sector level since $1970 .{ }^{1}$ At first sight, there is little evidence of a general decline in pricecost margins despite a steady increase in openness. In fact, at the aggregated manufacturing level, the price-cost margin was $9.4 \%$ in $1970,8.2 \%$ in 1980 , $11.5 \%$ in 1990 and $9.2 \%$ in 2003 . How could we reconcile these trends with the evidence of the pro-competitive effect of international trade highlighted above? In short, the effect of trade on the price-cost margin is not limited to its impact on the mark-up, because the price-cost margin only captures the part of the rents kept by the firms. Price-cost margins are therefore negatively related to the workers' bargaining power and therefore, a weakening of the workers' bargaining power may counterbalance a decrease in mark-ups.

\section{$<$ Insert Graph 1 about here>}

Taking into account labor market imperfections, Borjas and Ramey (1995) provide evidence of foreign competition exerting a negative impact on wages by reducing rents in concentrated sectors. However, the finding of lower rents per se does not mean that the rent-sharing scheme between capital and labor has changed. More recently, using a matched employer-employee database for France, Kramarz (2003) shows that outsourcing weakens the bargaining position of high-school graduate workers by limiting the availability of alternative jobs.

The seminal paper by Blanchard and Giavazzi (2003) draws attention to the importance of product and labor market interactions. Moreover, OECD studies (e.g. Brandt et al., 2005) point out that product and labor market deregulations are correlated across countries and Spector (2004) suggests that the effects of these deregulations tend to reinforce each other. Going one step further, endogenizing the bargaining regime, Ebell and Haefke (2004) argue that the strong

\footnotetext{
${ }^{1}$ Price-cost margin is defined, as in Schmalensee (1989, p.960), as the difference between revenue and variable cost over revenue. The variable cost is the sum of the costs of variable inputs, i.e. labor and materials.
} 
decline in coverage and unionization in the US and the UK might have been a direct consequence of product market reforms of the early eighties. Our study suggests that the trend in UK price-cost margins is the result of the joint decline in the mark-up and the workers' bargaining power following increased opening of the economy, along the lines of Blanchard (1997) for the United States.

We contribute to the literature in different ways. We take advantage of a rich firm-level dataset consisting of 9820 firms in the UK manufacturing industry covering the period 1988-2003. This enables us to estimate mark-up and workers' bargaining power parameters simultaneously for 20 sectors split according to 3 firm size categories and 3 time periods. To our knowledge, investigating the cross-sectional heterogeneity in the two parameters at this level of disaggregation has never been carried out for the UK. Whereas previous empirical studies have tested the imports-as-market-discipline hypothesis either on the product market or on the labor market, our study bridges the gap by verifying the impact of increased import competition on both mark-ups and workers' bargaining power parameters.

We follow a two-stage approach in which we first estimate mark-ups and workers' bargaining power parameters according to three dimensions (sector, firm size and time period). Our results point to a significant drop in both parameters in the mid-nineties. In the second stage, we identify factors explaining mark-ups and the workers' bargaining power with a special focus on the pro-competitive effect of international trade. We find clear evidence of imports from developed countries having contributed significantly to the decline in both mark-ups and workers' bargaining power.

In the remainder, we first describe the theoretical framework and the empirical strategy (section 2). Section 3 concentrates on the first-stage results. Section 4 discusses the second-stage results where we evaluate the pro-competitive effect on both mark-ups and the workers' bargaining power. Section 5 concludes.

\section{Methodology}

\subsection{Theoretical Framework}

Theoretically, we rely on the model of Crépon et al. (1999, 2002), detailed further by Dobbelaere (2004). We start from a production function $Q_{i t}=$ $\Theta_{i t} F\left(N_{i t}, M_{i t}, K_{i t}\right)$, where $i$ is a firm index, $t$ a time index, $N$ is labor, $M$ is material input, $K$ is capital and $F($.$) is assumed to be homogeneous of degree$ one in its arguments. $\Theta_{i t}$ is an index of technical change or "true" total factor productivity. The logarithmic differentiation of the production function gives:

$$
\Delta q_{i t}=\varepsilon_{N_{i t}}^{Q} \Delta n_{i t}+\varepsilon_{M_{i t}}^{Q} \Delta m_{i t}+\varepsilon_{K_{i t}}^{Q} \Delta k_{i t}+\Delta \theta_{i t}
$$

Each firm operates under imperfect competition in the product market. On the labor side, we assume that the union and the firm are involved in an efficient 
bargaining procedure with both wages $(w)$ and labor $(N)$ being the subject of an agreement (McDonald and Solow, 1981). The union is risk neutral and its objective is to maximize $U\left(w_{i t}, N_{i t}\right)=N_{i t} w_{i t}+\left(\bar{N}_{i t}-N_{i t}\right) \bar{w}_{i t}$, where $\bar{N}_{i t}$ is union membership $\left(0<N_{i t} \leq \bar{N}_{i t}\right)$ and $\bar{w}_{i t}$ is the alternative wage $\left(\bar{w}_{i t} \leq w_{i t}\right)$. Consistent with capital quasi-fixity, the firm objective is to maximize its shortrun profit function: $\pi\left(w_{i t}, N_{i t}, M_{i t}\right)=R\left(N_{i t}, M_{i t}\right)-w_{i t} N_{i t}-j_{i t} M_{i t}$, where $R_{i t}=P_{i t} Q_{i t}$ stands for total revenue. The outcome of the bargaining is the asymmetric generalized Nash solution to:

$$
\begin{aligned}
& \max _{w_{i t}, N_{i t}, M_{i t}}\left\{N_{i t} w_{i t}+\left(\bar{N}_{i t}-N_{i t}\right) \bar{w}_{i t}-\bar{N}_{i t} \bar{w}_{i t}\right\}^{\phi_{i t}}\left\{R_{i t}-w_{i t} N_{i t}-j_{i t} M_{i t}\right\}^{1-\phi_{i t}} \\
= & \max _{w_{i t}, N_{i t}, M_{i t}}\left\{N_{i t}\left(w_{i t}-\bar{w}_{i t}\right)\right\}^{\phi_{i t}}\left\{R_{i t}-w_{i t} N_{i t}-j_{i t} M_{i t}\right\}^{1-\phi_{i t}}
\end{aligned}
$$

where $\phi_{i t} \in[0,1]$ represents the workers' bargaining power.

Maximization with respect to material input gives $R_{M, i t}=j_{i t}$, which directly leads to:

$$
\varepsilon_{M_{i t}}^{Q}=\mu_{i t} \alpha_{M_{i t}}
$$

with $\mu_{i t}=\frac{P_{i t}}{C_{Q, i t}}$ and $\alpha_{M_{i t}}=\frac{j_{i t} M_{i t}}{P_{i t} Q_{i t}}$. Maximization with respect to employment and the wage rate respectively gives the following first-order conditions:

$$
\begin{aligned}
& w_{i t}=R_{N, i t}+\phi_{i t}\left[\frac{R_{i t}-R_{N, i t} N_{i t}-j_{i t} M_{i t}}{N_{i t}}\right] \\
& w_{i t}=\bar{w}_{i t}+\frac{\phi_{i t}}{1-\phi_{i t}}\left[\frac{R_{i t}-w_{i t} N_{i t}-j_{i t} M_{i t}}{N_{i t}}\right]
\end{aligned}
$$

Eq. (5) states that the wage premium over the alternative wage is positively related to the workers' bargaining power and to the size of the rents. Solving simultaneously (4) and (5) leads to an expression for the contract curve: $R_{N, i t}=$ $\bar{w}_{i t}$. Expressing the marginal revenue of labor as $R_{N, i t}=R_{Q, i t} Q_{N, i t}=\frac{P_{i t} Q_{N, i t}}{\mu_{i t}}$ and using this expression together with (4) and the expression for the contract curve, the elasticity of output with respect to employment can be written as:

$$
\varepsilon_{N_{i t}}^{Q}=\mu_{i t} \alpha_{N_{i t}}-\mu_{i t} \frac{\phi_{i t}}{1-\phi_{i t}}\left(1-\alpha_{N_{i t}}-\alpha_{M_{i t}}\right)
$$

with $\alpha_{N_{i t}}=\frac{w_{i t} N_{i t}}{P_{i t} Q_{i t}}$. Assuming constant returns to scale $\left(\varepsilon_{N_{i t}}^{Q}+\varepsilon_{M_{i t}}^{Q}+\varepsilon_{K_{i t}}^{Q}=1\right){ }^{2}$ the capital elasticity can be expressed as:

$$
\varepsilon_{K_{i t}}^{Q}=1-\mu_{i t} \alpha_{M_{i t}}-\mu_{i t} \alpha_{N_{i t}}+\mu_{i t} \frac{\phi_{i t}}{1-\phi_{i t}}\left(1-\alpha_{N_{i t}}-\alpha_{M_{i t}}\right)
$$

\footnotetext{
${ }^{2}$ The asumption of constant returns to scale is motivated by the large problem of identification which arises when mark-up and scale elasticity parameters are estimated simultaneously.
} 
Inserting (3), (6) and (7) in (1) and rearranging terms gives following expression of the Solow Residual $S R_{i t}$ :

$$
\begin{aligned}
S R_{i t} \equiv & \Delta q_{i t}-\alpha_{N_{i t}} \Delta n_{i t}-\alpha_{M_{i t}} \Delta m_{i t}-\left(1-\alpha_{N_{i t}}-\alpha_{M_{i t}}\right) \Delta k_{i t} \\
= & \beta_{i t}\left(\Delta q_{i t}-\Delta k_{i t}\right)-\gamma_{i t}\left(1-\alpha_{N_{i t}}-\alpha_{M_{i t}}\right)\left(\Delta n_{i t}-\Delta k_{i t}\right) \\
& +\left(1-\beta_{i t}\right) \Delta \theta_{i t}
\end{aligned}
$$

where $\beta_{i t}=\frac{\mu_{i t}-1}{\mu_{i t}}$ is the Lerner index and $\gamma_{i t}=\frac{\phi_{i t}}{1-\phi_{i t}}$, strictly increasing functions of the mark-up and the bargaining power, respectively.

By embedding the efficient bargaining model into a microeconomic version of Hall's (1988) framework, the Solow Residual can be broken down into three components: $(1)$ a factor representing the Lerner index $\left(\beta_{i t}\right),(2)$ a factor reflecting the relative bargaining power of the workers $\left(\gamma_{i t}\right)$ and (3) a technological term $\left(\Delta \theta_{i t}\right)$. Note that estimating mark-ups relying on the original Hall (1988) approach, assuming allocative wages, generates a downward bias, which increases with the bargaining power of the workers. Intuitively, this underestimation corresponds to the omission of the part of product rents captured by the workers (see Dobbelaere, 2004 and Dobbelaere and Mairesse, 2005 for sector-level evidence in the Belgian and the French manufacturing industry respectively).

\subsection{Empirical Framework}

To test the imports-as-product-and-labor-market-discipline hypothesis, we follow a two-stage estimation strategy. In the first part, we estimate the reducedform equation (8) which allows us to identify our structural parameters of interest, i.e. the price-marginal cost mark-up $\hat{\mu}$ and the workers' bargaining power $\widehat{\phi}$. We estimate these parameters for 20 sectors in the UK manufacturing industry, split according to 3 size categories and 3 time periods. In the second part, our estimated parameters are regressed on international trade variables to test the hypothesis that international competition curtails domestic product and labor market power.

\section{Part I : Identifying the parameters of interest $\hat{\mu}$ and $\widehat{\phi}$}

In this section, we first present the data. Second, we outline our empirical strategy and compare consistently fixed effects (FE) and Generalized Method of Moments (GMM) estimates of our parameters of interest at the sectoral level for all firms and all periods. Finally, we conduct a variance analysis along the three dimensions, sector, firm size and period.

\subsection{Data}

Our analysis is based on two firm-level surveys: OneSource, which covers the years 1988-1998, and Financial Analysis Made Easy (FAME), which offers a 
coverage for the years 1994-2003. ${ }^{3}$ We only keep firms within the manufacturing industry for which we have at least 4 observations for all variables, ending up with an unbalanced panel of 9820 firms with the number of observations for each firm varying between 4 and $14 .^{4}$

We use turnover deflated by the producer price index at the four- and five-digit level, according to availability, ${ }^{5}$ as a proxy for output $(Q)$. Labor $(N)$ refers to the average number of employees in each firm for each year. Intermediate inputs $(M)$ are calculated by subtracting the value added from the value of production, deflated by the two-digit materials and fuel price index. The capital stock $(K)$ is measured by the gross bookvalue of fixed assets deflated by a price index of net capital defined at the two-digit level. All deflators are drawn from the UK Office for National Statistics (ONS). The input shares $\left(\alpha_{N}\right.$ and $\left.\alpha_{M}\right)$ are computed by dividing respectively the firm total labor cost and undeflated intermediate inputs by the value of production and by taking the average of these ratios over adjacent years. Table 1 reports the means, standard deviations and first and third quartiles of our main variables used in the Part I estimation. ${ }^{6}$

\section{$<$ Insert Table 1 about here>}

We split the total sample into 20 two-digit sectors according to the Standard Industrial Classification 2003. ${ }^{7}$ Employment coverage of our sample is on average $60 \%$ of total UK manufacturing employment (SIC 15-37). Table A.1 in Appendix shows the sector repartition of the sample.

\subsection{Empirical Strategy}

The main difficulty in estimating the extended Hall-type equation (8) lies in the potential correlation between the TFP-growth term $(\Delta \theta)$ and the RHS variables. The problem arises because the productivity shocks are unobserved by the econometrician but not necessarily by the firms which, at least, might anticipate them before choosing their factor inputs. In this case, OLS estimates are likely to be biased. Moreover, the burgeoning literature on firm heterogeneity stresses the differences in productivity level and growth across firms (Bernard et

\footnotetext{
${ }^{3}$ OneSource is a database of company accounts constructed by OneSource Information Services Ltd, whilst FAME is gathered by Bureau Van Dijk Electronic Publishing and both derive ultimately from the information which companies are required to deposit at Companies House. For FAME a maximum of 10 years of complete data history can be downloaded at once. For OneSource we used the CD-ROM entitled "UK companies, Vol. 1", October 2000. Further details on the OneSource dataset can be found in Oulton (1998).

${ }^{4}$ In OneSource, the holding companies are reported in addition to their subsidiaries. To avoid the double accounting, we excluded the holdings.

${ }^{5}$ The PPI is available at the 5-digit level for the period 1990-2000 and at the 4-digit level for the period 2001-2003.

${ }^{6}$ We made two rounds of cleaning: the first in order to harmonize OneSource with Fame and to obtain a unique and coherent dataset, and the second to eliminate outliers and anomalies in the dataset. Details are available upon request.

${ }^{7}$ We paid attention to the fact that some firms were recorded in two sectors at different times. To create a one-to-one match between firms and sectors, each firm was attributed to the most recorded sector. Sectors 16 and 23 have been dropped due to parsimonious data.
} 
al., 2003 for the US and Eaton et al., 2004 for France). As in Harrison (1994), this problem could be addressed by decomposing the productivity growth term into a firm and a time fixed effect, the latter capturing possible unobservable aggregate shocks and productivity shocks common to all firms within sector $j$, plus a disturbance term:

$$
u_{i j t}=\left(1-\beta_{j}\right) \Delta \theta_{i j t}=e_{i j}+e_{j t}+v_{i j t}
$$

However, since inputs and output are simultaneously determined, the fixedeffects (FE) estimator might still be biased. Taking advantage of the panel dimension of the data, Eq.(8) can be estimated using the Generalized Method of Moments (GMM) technique. We use the 3- to 5-year lagged values of the factor inputs $n, m$ and $k$ as instruments.

\subsection{Comparison of FE and GMM estimates}

Table 2 reports the $\mathrm{FE}$ and $\mathrm{GMM}^{8}$ estimates for each of the 20 sectors. ${ }^{9}$ For the GMM estimates, the parameters of interest $\left(\hat{\mu}_{j}\right.$ and $\left.\widehat{\phi}_{j}, j=1, \ldots, 20\right)$ are computed from the two-step estimated values of the reduced-form coefficients $\left(\widehat{\beta}_{j}\right.$ and $\widehat{\gamma}_{j}$ respectively). The estimated standard errors $(\widehat{\sigma})$ of the estimated parameters are computed using the Delta Method (Woolridge, 2002). ${ }^{10}$

The estimated Lerner index $\left(\widehat{\beta}_{j}\right)$ is always very significant. The estimated relative bargaining power of the workers $\left(\widehat{\gamma}_{j}\right)$ is significant for 18 out of the 20 sectors with FE, and this number drops to 10 with GMM. However, average parameters are very similar, around 0.20 for $\widehat{\beta}_{j}$ and 0.70 for $\widehat{\gamma}_{j}$, which implies an average estimated mark-up $\left(\hat{\mu}_{j}\right)$ of 1.25 and an average estimated workers' bargaining power parameter $\left(\widehat{\phi}_{j}\right)$ of 0.40 respectively. The latter is above Van Reenen's (1996) estimates, lying in (0.22-0.29) range, but is very close to the UK estimates obtained by Dumont et al. (2006) using a smaller set of firms and sectors. More specifically, the FE range across sectors is $(1.12-1.45)$ for the estimated mark-up and (0.19 - 0.56) for the estimated workers' bargaining power. The GMM specification tests behave well. The overidentification test is not rejected in all but two sectors. The autocorrelation tests are not rejected for sixteen sectors. ${ }^{11}$

It is worth noting that the estimated mark-up $\left(\hat{\mu}_{j}\right)$ and the estimated workers' bargaining power parameter $\left(\widehat{\phi}_{j}\right)$ are positively correlated across sectors. The

\footnotetext{
${ }^{8}$ The GMM estimation was carried out in Stata 9.1 (Roodman, 2005).

${ }^{9}$ Note that a considerable share of firms generates negative profits in a given year. For instance, the sum of the shares of variable factors in output exceeds 1 for $21 \%$ of the observations in our sample, which is not uncommon. In this case, Eq.(8) is not symmetrical as bargaining does not apply to negative profits. In particular, wages cannot be lower than the marginal revenue of labor. It follows directly that $\left(1-\alpha_{N_{i t}}-\alpha_{M_{i t}}\right)\left(\Delta n_{i t}-\Delta k_{i t}\right)$ in (8) equals zero when the sum of the variable input shares exceeds one. We also tried to limit the sample to those observations of which the sum of the variable input factors is lower than 1.05 and found similar results.

${ }^{10} \sigma_{\widehat{\mu}}=\frac{\sigma_{\widehat{\beta}}}{(1-\widehat{\beta})^{2}} ; \sigma_{\widehat{\phi}}=\frac{\sigma_{\widehat{\gamma}}}{(1+\widehat{\gamma})^{2}}$.

${ }^{11}$ Results not reported but available upon request.
} 
correlation between the two estimated structural parameters is 0.71 for the $\mathrm{FE}$ estimates and 0.53 for the GMM estimates. This is consistent with Abowd and Lemieux (1993) findings that the bargaining power is positively linked to the size of the rents, and with Dobbelaere (2004) and Dobbelaere and Mairesse (2005). Boulhol (2005) suggests that, as capital return is determined by the share of the rents kept by the firms, an arbitrage reasoning based on capital mobility across sectors can explain this positive correlation.

\section{$<$ Insert Table 2 about here>}

Table 3 compares the FE and the GMM estimates more synthetically. The GMM estimates are more dispersed across sectors, even leading to two (insignificant) negative bargaining power parameters. However, the correlation between the FE and the GMM estimates is strong and significant. For the estimated Lerner indexes, the Pearson correlation coefficient is close to 0.90 between FE and GMM. For the estimated relative bargaining power parameters, it reaches 0.57 unweighted and 0.72 when weighted to take into account the precision of the estimates. This comparison highlights that the FE and the GMM estimates are very close to each other and suggests that the fixed effects do a good job in accounting for the heterogeneity in productivity growth across firms. Dobbelaere and Mairesse (2005) reach a similar conclusion. Harrison (1994) shows that her FE and IV estimates are very close and, consequently, sticks to the FE results as Levinsohn (1993) does. We follow the same route for the remaining of this study.

$$
<\text { Insert Table } 3 \text { about here> }
$$

\subsection{Variance Analysis}

The above estimates should be considered as sectoral average parameters. There are, however, many reasons to believe that mark-up and bargaining power parameters vary across time and firm size. What follows confirms this presumption. In addition to the sectoral dimension, the sample is split according to size and period criteria. For the former, the sample is divided between small firms (fewer than 75 employees on average), medium-sized firms (between 75 and 200 employees) and large firms (more than 200 employees), which provides three sub-samples of comparable size. For the latter, three sub-periods are defined: 1991-1994, 1995-1998, 1999-2003. ${ }^{12}$ This leaves us with 179 estimates for the mark-up and the bargaining power parameter: 20 sectors $\mathrm{x} 3$ periods $\mathrm{x} 3$ size classes, minus sector 19, first period, small firms due to lack of data.

These 179 "observations" are used in our Part II estimates. Before formally assessing the determinants of the two parameters of interest, we conduct a variance analysis along the three dimensions presiding over the splitting of the sample. Each of these Part I estimates is weighted by the inverse of the sampling variance. 19 out of the 179 Part I estimates display a negative estimated bargaining

\footnotetext{
${ }^{12}$ We start in 1991 to allow for lags.
} 
power. Therefore, as a robustness check, the various results are compared with and without the 19 "outliers".

As for the estimated mark-ups (see the left part of Table 4), the three dimensions (sector, size and period) are very significant at the $99 \%$ confidence level, the sectoral dimension, as expected, accounting for the larger part of the explained variance. Two findings show up clearly. First, mark-ups drop significantly and importantly by around five percentage points between the first and the second period. Second, the estimated mark-up is increasing in firm size. This is consistent with both theory (e.g. Cournot competition) and empirical evidence in the heterogeneous firm literature. The difference according to firm size is especially true between the small firms and the others.

The right part of Table 4 reports the variance analysis for the estimated workers' bargaining power parameters. The sector share of the explained variance is also predominant. Similar to the estimated mark-up, the workers' bargaining power dropped significantly, by around 0.12 , after the first period. This decrease in the workers' bargaining power echoes Blanchflower and Bryson (2004) who find a significant decline in the union wage premium after 1994 for the UK. It is also consistent with the diluted role of UK labor market institutions, documented by Machin (1997). In addition to other legislative measures, he draws attention to the abolition of the Wages Council system of minimum wages in August 1993, covering 2.5 million workers at that time. Moreover, the workers' bargaining power is estimated to be lower, by around 0.05, for the smaller firms. However, this difference is only significant with the medium-sized firms. ${ }^{13}$

$<$ Insert Table 4 about here>

\section{Part II : Testing the imports-as-product-and- labor-market-discipline hypothesis}

This section concentrates on the identification of the effect of increased import competition on the estimated mark-ups and workers' bargaining power parameters. Each Part I estimate is weighted by the inverse of the sampling variance. A description of all variables used in this section and data sources are reported in table A.2 in Appendix. Our main focus is the impact of international trade on our two parameters of interest.

\subsection{Mark-up}

\subsubsection{Specification}

Firms under intensifying foreign competition are induced to reduce their margins because of the increase in the perceived elasticity of the demand they are facing.

${ }^{13}$ When we drop the 19 "outliers", we find very similar results. 
This elasticity depends on the elasticity of substitution between varieties, the concentration level and the intensity of competition.

The following variables are defined. IMPORT is the share of imports in sectoral demand. Trade theory highlights that the impact of imports is differentiated depending on the origin of the imports. For a developed country like the United Kingdom, trade with developing countries is supposedly based on comparative advantage and the impact of trade is mainly channelled through reallocation between sectors. In contrast, trade with developed countries is mostly intra-industry. It is based on imperfect competition and is therefore a better candidate for the pro-competitive effect on markups. We distinguish IMPNORTH, which is the share of imports from Western Europe, North America, Japan, Australia and New Zealand in total demand, from IMPSOUTH, its complement. Since firms are likely to select foreign markets based on the margins they offer for their products, exports could be positively related to markups. The export ratio at the firm level is EXPFIRM.

The relationship between the intensity of competition and concentration need not be monotonous. Indeed, Sutton (1991, 1997) insists on the endogeneity of market structure. An increase in the competitive environment may trigger an endogenous reaction of firms, through an increase in $R \& D$ or advertisement spending for instance. This might force out firms that are unable to keep the pace. R\&D could hence be positively related to mark-ups. R\&DRATIO is defined as the share of R\&D spending in total output at the sectoral level.

There is a lack of data to take into account the change in domestic competition at the sectoral level. At the country level, we test three variables that might have an impact on markups. $P M R$ is the product market regulation index computed by the OECD on a scale from 0 to 6 , in ascending order of regulation. The series is available for 1988, 1993, 1998 (Nicoletti et al., 2001) and 2003 (Conway et al., 2005), and is linearly interpolated between these years. ${ }^{14}$ For the UK, it has decreased from 3.5 in 1988 to 1.0 in 2003. The second variable is the (log of) stock market capitalization as a share of GDP, CAPIT. Hoekman et al. (2001) provide evidence of stock market capitalization exerting a significantly positive impact on average industry mark-ups. They argue that financial deepening reduces the cost of capital, thus increasing the overal profitability of the economy. Finally, the Herfindahl index, $H E R F$, is calculated from our sample. Caution is required using this variable as it is very sensitive to the entry or exit of big firms in the database at different times.

Because of its importance in the drawing up of macroeconomic policies, an abundant literature deals with the cyclicality of mark-ups. Rotemberg and Woodford (1999) provide some detailed theoretical explanations, such as overhead labor, adjustment costs and labor hoarding, in support of the counter-cyclicality

\footnotetext{
${ }^{14}$ The indicator is based on seven non-manufacturing sectors (energy, communication and transport). It is very correlated (linear coefficient of around 86\%) to the regulation index for the whole economy, only available for 1998 and 2003.
} 
of mark-ups. The debate whether mark-ups are pro- or counter-cyclical remains unresolved although the empirical evidence rather leans towards countercyclicality. We use the annual change in value-added, and $V A L U C Y C$ is the de-trended series using a Hodrik-Prescott filter. Our empirical specification can be expressed as:

$\widehat{\mu}_{j s p}=\alpha_{1} \operatorname{Lag}\left(\operatorname{IMPORT}_{j p}\right)+\alpha_{2} \operatorname{Lag}\left(\operatorname{EXPFIR}_{j s p}\right)+\alpha_{x} X_{j s p}+e_{j}+e_{s}+e_{p}+\xi_{j s p}$

with $j, s$ and $p$ indexing sector, size and period, respectively.

To overcome the endogeneity problem of trade and other variables, all explanatory variables are lagged, except for firm size, the cyclical variable and the Herfindahl index. We use 3-year lagged values of the endogenous variables. In order to avoid overlapping between the subperiods, ideally we would need 5year lags. However, such a long lag is likely to weaken the explanatory power substantially and we therefore use it as a robustness check only.

\subsubsection{Results}

Our results are presented in Table 5. The main result is that imports exert a negative impact on mark-ups, although this effect is not significant when the origin of imports is not differentiated. As column (2) indicates, this is because only imports from developed countries appear to have a significant effect, which is consistent with the discussion above. The estimated impact looks strong, as an increase of one point in the share of imports from the North in total demand would trigger a decrease of around one point. Kee and Hoekman (2003), Chen et al. (2004) and Boulhol (2006) found about half the size of this effect, although without distinguishing between the origin of imports. Note that, compared to the variance analysis, the explanatory power measured by the adjusted $\mathrm{R}^{2}$ increases from 0.31 to 0.36 .

Exports never show up as being significant. Consistent with the heterogenous firm literature, we find that exports increase with firm size, as the export ratio is on average 0.065 higher for the large compared to the small firms. However, it seems that the size-effect on mark-ups is not amplified by the export status.

$\mathrm{R} \& \mathrm{D}$ appears to have a positive effect on mark-ups. Although not always significant, the impact is large as one standard deviation in R\&DRATIO makes a difference of 0.07 in mark-ups. When we substitute the (log of) average employment to the size dummies or when the sample is restricted to the positive bargaining power observations, the results are not altered. When time dummies are withdrawn, the coefficient of the cyclical variable $V A L U C Y C$ is negative and significant, hence supporting the counter-cyclicality of mark-ups.

As a robustness check, we use 5-year lags which produce in general qualitatively similar -although not always significant- results. As an illustration, we report in the last column the specification consistent with the one in column (2).

$<$ Insert Table 5 about here> 


\subsection{Workers' Bargaining Power}

\subsubsection{Specification}

Formalizing the impact of foreign competition on workers' bargaining strength is not as straightforward as doing so on mark-ups, even if it is generally reflected in the increase in the elasticity of labor demand due to imports. Rodrik (1997) points out that imports increase the substitution between domestic and foreign workers. Moreover pressure from foreign competition could increase the risk of breakdown in bargaining and loosen labor market tightness, thereby diminishing workers' bargaining power (see Brock and Dobbelaere, 2006 and Dumont et al.,2005 for further discussion and references).

In addition to the variables described in Section (4.1.1), we evaluate the effect of three labor market variables on workers' bargaining power: UNIONDENS, $R E P L R A T E$ and $U N E M P R A T E$, referring to union density, the replacement rate and the unemployment rate at the country level respectively. Union density and the replacement rate are expected to be positively related to the workers' bargaining power. For the unemployment rate, the link might not be clear-cut. An increase in the unemployment rate has a negative effect on the outside option, hence a negative relationship with the workers' bargaining power is expected. However, because the union wage premium softens the impact of shocks on wages, Blanchflower and Bryson (2004) find that the union wage premium is counter-cyclical, pointing to a positive relationship. Therefore, the resulting effect is, a priori, ambiguous.

Product market deregulation $(P M R)$ has been found to be positively correlated to labor market deregulation across countries and seems to precede labor market reforms (see Fig. 34 in Brandt et al., 2005). If capital deepening (CAPIT) is linked to increased capital mobility, it might have a negative impact on the workers' bargaining power. Finally, it is often argued that technological change, instead of international trade, triggers changes in the labor market (see e.g. Berman et al., 1994; Krugman and Lawrence, 1996). Technological change ( $R \& D R A T I O)$ might exert an effect on the workers' bargaining power by impacting the nature of the production process. However, this effect is, a priori, unclear. As discussed in Betcherman (1991), it depends on the importance of labor costs in the firm's total costs and on the workers' essentiality in the production process.

To test the imports-as-labor-market discipline hypothesis, we estimate the following specification:

$\widehat{\phi}_{j s p}=\alpha_{1} \operatorname{Lag}\left(\operatorname{IMPORT}_{j p}\right)+\alpha_{2} \operatorname{Lag}\left(\operatorname{EXPFIR}_{j s p}\right)+\alpha_{x} X_{j s p}+e_{j}+e_{s}+e_{p}+\xi_{j s p}$

with $j, s$ and $p$ indexing sector, size and period, respectively. 


\subsubsection{Results}

Our results, which are reported in Table 6, provide robust evidence of imports having squeezed the workers' bargaining power. When the origin is taken into account, this impact is only significant for imports from developed countries. An increase of one point in the share of imports from the North seems to have reduced the bargaining power by 0.08 on average. ${ }^{15}$ The fact that only increased import competition from the North exerts a significantly negative impact might seem surprising at first sight. However, one would need to rely on a more detailed skill structure within sectors to have a clearer analysis. Our results seem to point out that, because of similar characteristics in terms of education, productivity and skills, foreign workers in developed countries are more substitutable through imports to UK workers than those in developing countries. Interestingly, Neven and Wyplosz (1999) find similar effects. In addition, the coefficient on EXPFIRM is positive and significant at $10 \%$ for a few specifications.

Because most of the other explanatory variables lack the sectoral dimension, we run into severe multicollinearity issues. This makes it almost impossible to disentangle the effect of these country variables. Therefore, we test each of them separately, keeping in mind that the contribution of each variable should not be cumulated. The impact of UNIONDENS, PMR, REPLRATE, CAPIT and UNEMPRATE show up significantly. The first two variables have the highest explanatory power. De-unionization seems to be associated with a decline in the workers' bargaining power between 1991 and 2003. Product market and labor market deregulation are found to go hand in hand. A higher unemployment rate, a lower replacement rate and financial deepening seem negatively related to the workers' bargaining power. Finally, the workers' bargaining power is found to be significantly higher in concentrated sectors whereas no significant relationship is detected with $R \& D .{ }^{16}$

$<$ Insert Table 6 about here $>$

\section{Conclusion}

Many empirical studies have provided evidence that trade has a pro-competitive effect by reducing mark-ups to marginal cost in import competing industries. Most of them have focused on developing countries assuming a perfectly competitive labor market. In contrast, this study concentrates on a developed country and takes into account labor market imperfections, using firm-level data for UK manufacturing sectors. Our results indicate that both the mark-ups and workers' bargaining power decreased in the mid-nineties. Moreover, imports

\footnotetext{
${ }^{15}$ Considering 5 EU countries (Belgium, France, Germany, Italy and the UK), Dumont et al. (2006) find a comparable effect.

${ }^{16}$ As a robustness check, limiting ourselves to the 160 non-negative bargaining power Part I estimates produces similar results. Also, we used a logarithmic transformation. The results, which are available upon request, confirm our previous findings.
} 
from developed countries are shown to contribute significantly to these changes, whereas firm exports have a weakly significant positive influence on the workers' bargaining power. These joint effects imply that trade has exerted a conflicting impact on price-cost margins, i.e. on the share of the rents kept by the firms. We also find, consistent with the recent literature on firm heterogeneity, that small firms have lower mark-ups. Additionally, their workers are subject to a lower bargaining power. 


\section{Appendix}

Table A.1

Sector repartition of the sample

\begin{tabular}{ll}
\hline Code & Name \\
\hline 15 & Food products and beverages \\
17 & Textiles \\
18 & Wearing apparel, dressing, dying of fur \\
19 & Leather, leather products and footwear \\
20 & Wood and products of wood and cork \\
21 & Pulp, paper and paper products \\
22 & Printing and publishing \\
24 & Chemicals and chemical products \\
25 & Rubber and plastic products \\
26 & Other non-metallic mineral products \\
27 & Basic metals \\
28 & Fabricated metal products, except machinery and equipment \\
29 & Machinery and equipment, n.e.c. \\
30 & Office, accounting and computing machinery \\
31 & Electrical machinery and apparatus, n.e.c. \\
32 & Radio, television and communication equipment \\
33 & Medical, precision and optical instruments \\
34 & Motor vehicles, trailers and semi-trailers \\
35 & Other transport equipment \\
36 & Manufacturing, n.e.c. \\
\hline
\end{tabular}

Table A.2

Description and source of variables in Part II regressions

\begin{tabular}{lll}
\hline Variable & Description & Source \\
\hline CAPIT & Log of stock market capitalization & Datastream \\
EXPFIRM & Firm a percentage of GDP & OneSource, FAME \\
HERF & Sample-based Herfindahl index & OneSource, FAME \\
IMPORT & Sectoral import penetration ratio: & STAN \\
& imports/(imports+production-exports) & \\
IMPNORTH & IMPORT from Western Europe, North America, & Bilateral Trade Database (OECD) \\
IMPSOUTH & Japan, Australia and New Zealand & Bilateral Trade Database (OECD) \\
PMR & Complement of IMPNORTH & Conway et al. (2005) \\
R\&DRATIO & Product market regulation index & OECD \\
UNEMPRATE & Coctoral share of R\&D expenses in total output & Nickell and Nunziata (2001) \\
UNIONDENS & Manufacturing-level union density & Nickell and Nunziata (2001) \\
REPLRATE & Manufacturing-level replacement rate & Nickell and Nunziata (2001) \\
VALUCYC & De-trended sectoral annual change in value added & STAN \\
\hline
\end{tabular}




\section{References}

[1] Abowd, J. and T. Lemieux, 1993, The effects of product market competition on collective bargaining agreements: The case of foreign competition in Canada, The Quarterly Journal of Economics, 108(4), 983-1014.

[2] Berman, E., J. Bound and Z. Griliches, 1994, Changes in the demand for skilled labor within US manufacturing. Evidence from the Annual Survey of Manufacturers, The Quarterly Journal of Economics, 109(2), 367-397.

[3] Bernard, A.B., J. Eaton. J.B. Jensen and S. Kortum, 2003, Plants and productivity in international trade, American Economic Review, 93(4), 12681290 .

[4] Betcherman, G., 1991, Does technological change affect union bargaining power?, British Journal of Industrial Relations, 29(3), 447-462.

[5] Blanchard, O., 1997, The medium run, Brooking Papers on Economic Activity $2,89-158$.

[6] Blanchard, O. and F. Giavazzi, 2003, Macroeconomic effects of regulation and deregulation in goods and labor markets, The Quarterly Journal of Economics, 118(3), 879-908.

[7] Blanchflower, D.G. and A. Bryson, 2004, The union wage premium in the US and the UK, CEP Discussion Paper 612, Centre for Economic Performance.

[8] Borjas, G.J. and V.A. Ramey, 1995, Foreign competition, market power and wage inequality, The Quarterly Journal of Economics, 110(4), 10751110.

[9] Boulhol, H., 2005, The convergence of price-cost margins, Cahiers de la MSE, Série blanche TEAM 05-56, Maison des Sciences Economiques.

[10] Boulhol, H., 2006, Why haven't price-cost margins decreased with globalisation?, Cahiers de la MSE, Série blanche TEAM 06-07, Maison des Sciences Economiques.

[11] Brandt, N., J.M. Burniaux and R.Duval, 2005, Assessing the OECD jobs strategy: Past development and reforms, OECD Working Paper 429, Organisation for Economic Co-operation and Development.

[12] Brock, E. and S. Dobbelaere, 2006, Has international trade affected workers' bargaining power?, Review of World Economics-Weltwirtschaftliches Archiv, 142(6), forthcoming.

[13] Chen, N., J. Imbs and A. Scott, 2004, Competition, globalization and the decline of inflation, CEPR Discussion Paper 4695, Centre for Economic Policy Research. 
[14] Conway, P., V. Janod and G. Nicoletti G., 2005, Product market regulation in OECD Countries: 1998 to 2003, OECD Working Paper 419, Organisation for Economic Co-operation and Development.

[15] Crépon, B., R. Desplatz and J. Mairesse, 1999, Estimating price-cost margins, scale economies and workers' bargaining power at the firm level, CREST Working Paper G9917, Centre de Recherche en Economie et Statistique.

[16] Crépon, B., R. Desplatz and J. Mairesse, 2002, Price-cost margins and rent sharing: Evidence from a panel of French manufacturing firms, Centre de Recherche en Economie et Statistique, revised version.

[17] Dobbelaere, S., 2004, Estimation of price-cost margins and union bargaining power for Belgian manufacturing, International Journal of Industrial Organization, 22(10), 1381-1398.

[18] Dobbelaere, S. and J. Mairesse, 2005, Cross-sectional heterogeneity in pricecost margins and the extent of rent sharing at the sector and firm level in France, IZA Discussion Paper 1898, Institute for the Study of Labor.

[19] Dumont, M., G. Rayp and P. Willemé, 2006, Does internationalization affect union bargaining power? An empirical study for five EU countries, Oxford Economic Papers, 58, 77-102.

[20] Eaton, J., S. Kortum and F. Kramarz, 2004, Dissecting trade: Firms, industries and export destinations, American Economic Review, 94(2), 150154.

[21] Ebell, M. and C. Haefke, 2004, The missing mink: Product market regulation, collective bargaining and the European unemployment puzzle, Society for Economic Dynamics, Meeting Papers 579.

[22] Hall, R.E., 1988, The relationship between price and marginal cost in US industry, Journal of Political Economy, 96, 921-947.

[23] Harrison, A., 1994, Productivity, imperfect competition and trade reform: Theory and evidence, Journal of International Economics, 36(1-2), 53-73.

[24] Hoekman, B., H.L. Kee and M. Olarreaga, 2001, Mark-ups, entry regulation and trade: Does country size matter?, CEPR Discussion Paper 2853, Centre for Economic Policy Research.

[25] Kee, H.L. and B. Hoekman, 2003, Imports, entry and competition law as market disciplines, CEPR Discussion Paper 3777, Centre for Economic Policy Research.

[26] Konings, J., P. Van Cayseele and F. Warzynski, 2001, The dynamics of industrial mark-ups in two small open economies: Does national competition policy matters?, International Journal of Industrial Organization, 19, 841-859. 
[27] Kramarz, F., 2003, Wages and international trade, CEPR Discussion Paper 3936, Centre for Economic Policy Research.

[28] Krishna, P. and D. Mitra, 1998, Trade liberalization, market discipline and productivity growth: New evidence from India, Journal of International Economics, 56, 447-462.

[29] Krugman, P. and R. Lawrence, 1996, Trade, jobs and wages, in: Krugman, P. (Ed.), Pop Internationalism, Cambridge: MIT Press.

[30] Levinsohn, J., 1993, Testing the imports-as-market-discipline hypothesis, Journal of International Economics, 35(1-2), 1-22.

[31] Machin, S., 1997, The decline of labour market institutions and the rise in wage inequality in Britain, European Economic Review, 41(3-5), 647-657.

[32] McDonald, I.M. and R.M. Solow, 1981, Wage bargaining and employment, American Economic Review, 71(5), 896-908.

[33] Neven, D. and C. Wyplosz, 1999, Relative prices, trade and restructuring in European industry, in: Dewatripont, M., Sapir, A., Sekkat, K. (Eds), Trade and jobs in Europe, much ado about nothing?, Oxford: Oxford University Press.

[34] Nickell, S.J. and L. Nunziata, 2001, Labour market institutions database, Centre for Economic Performance.

[35] Nicoletti, G., A. Bassanini, E. Ernst, S. Jean, P. Santiago and P. Swaim, 2001, Product and labour markets interactions in OECD countries, OECD Working Paper 312, Organisation for Economic Co-operation and Development.

[36] Rodrik, D., 1997, Has globalization gone too far?, Washington, DC: Institute for International Economics.

[37] Roodman, D., 2005, xtabond2: Stata module to extend xtabond dynamic panel data estimator. Center for Global Development, Washington.

[38] Rotemberg, J.J. and M. Woodford, 1999, The cyclical behavior of prices and costs, Handbook of Macroeconomics 1B, 1051-1135.

[39] Schmalensee, R., 1989, Inter-industry studies of structure and performance, in: Schmalensee, R., R. Willig (Eds.), Handbook of International Organisation, vol. 2, Chapter 16, North Holland, Amsterdam.

[40] Spector, D., 2004, Competition and the capital-labor conflict, European Economic Review, 48(1), 25-38.

[41] Van Reenen, J., 1996, The creation and rapture of rents: Wages and innovation in a panel of UK companies, The Quarterly Journal of Economics 111(1), 195-226. 
[42] Sutton, J., 1991, Sunk costs and market structure, Cambridge, MA: MIT Press.

[43] Sutton, J., 1997, Technology and market structure, Cambridge, MA: MIT Press.

[44] Windmeijer, F., 2005, A finite sample correction for the variance of linear efficient two-step GMM estimators, Journal of Econometrics, 126, 25-51.

[45] Woolridge, J., 2002, Econometric analysis of cross sections and panel data, Cambridge, MA: MIT Press. 


\section{Graph 1}

Price-cost margins for large UK manufacturing sectors (description in A.1 in Appendix)

1970-2003, STAN database

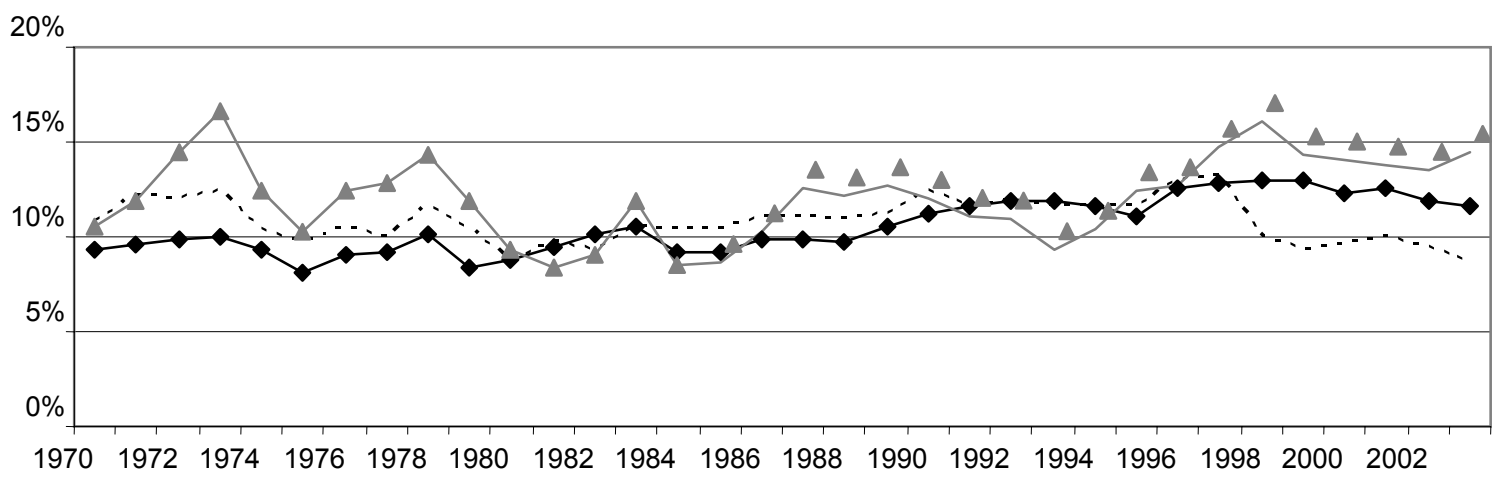

$$
\longrightarrow 15-16 \ldots \ldots-17-19 \longrightarrow 20
$$

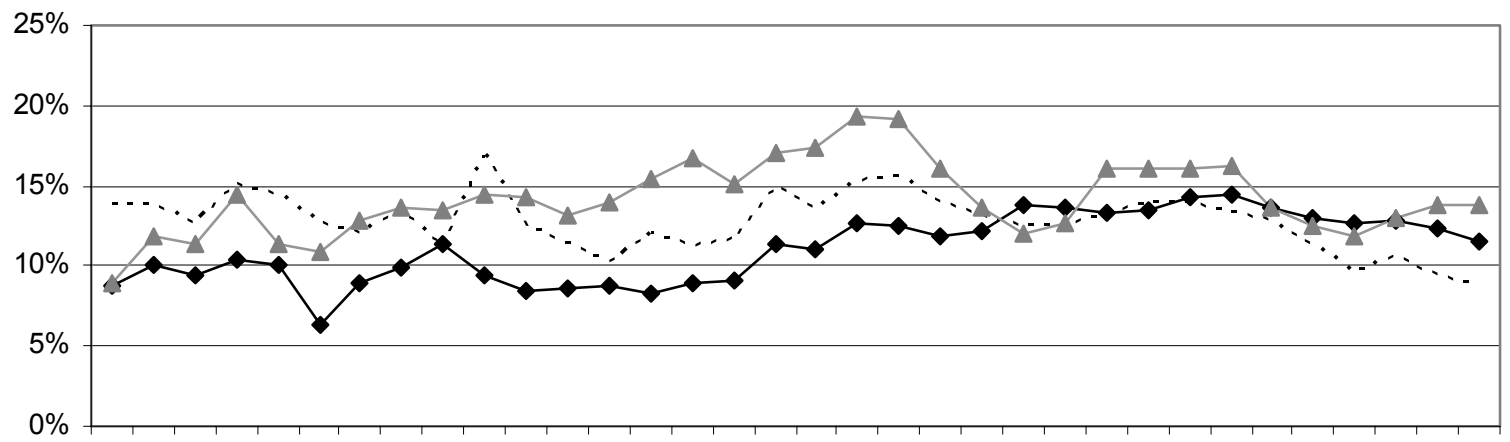

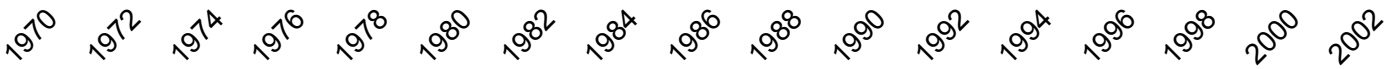

$$
\longrightarrow 21-22 \ldots \ldots . .23-25 \multimap 26
$$

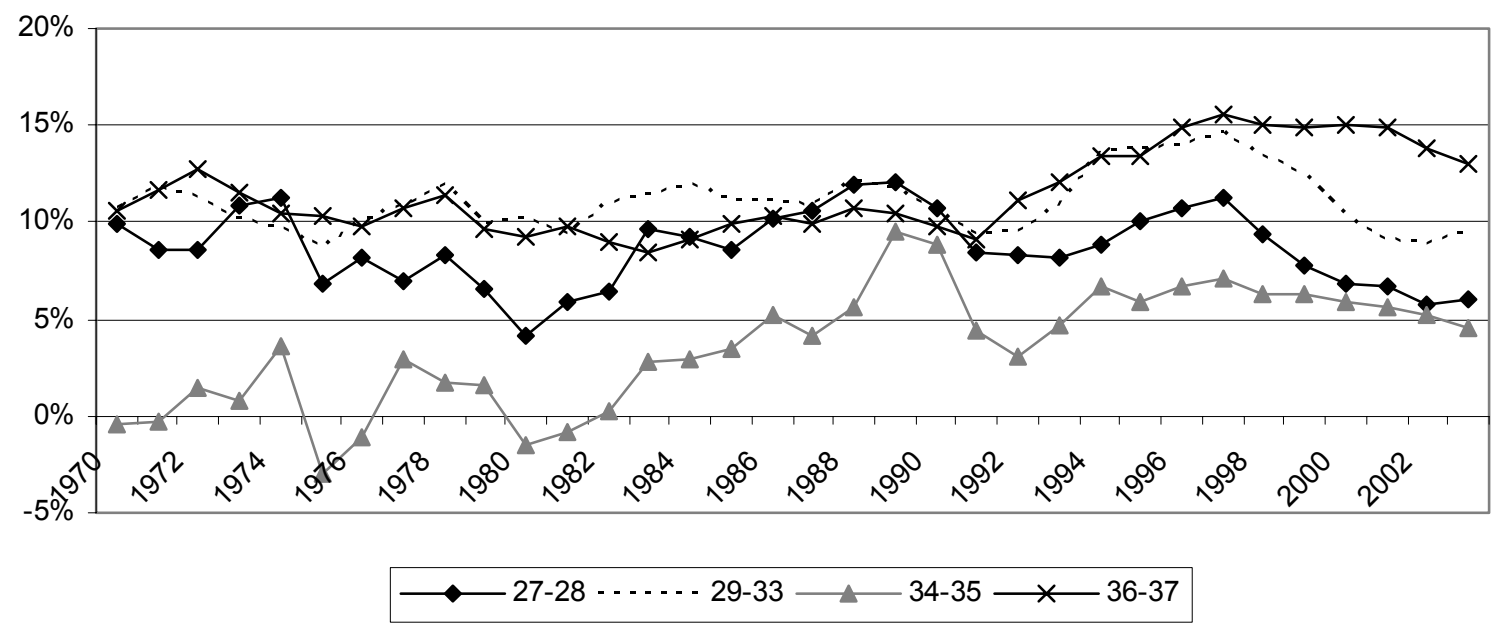


Table 1

Summary statistics

\begin{tabular}{llcccc}
\hline Variables & \multicolumn{5}{c}{$1990-2003$} \\
\hline & Mean & Sd. & $\mathrm{Q}_{1}$ & $\mathrm{Q}_{3}$ & $\mathrm{~N}$ \\
\hline Real firm output growth rate $\Delta q$ & 0.014 & 0.166 & -0.081 & 0.107 & 60579 \\
Labor growth rate $\Delta n$ & 0.003 & 0.129 & -0.061 & 0.062 & 60579 \\
Capital growth rate $\Delta k$ & 0.006 & 0.178 & -0.090 & 0.088 & 60579 \\
Intermediate inputs growth rate $\Delta m$ & 0.029 & 0.189 & -0.084 & 0.138 & 60579 \\
Share of labor in nominal output $\alpha_{N}$ & 0.287 & 0.130 & 0.192 & 0.369 & 60579 \\
Share of intermediate inputs in nominal output $\alpha_{M}$ & 0.656 & 0.137 & 0.567 & 0.752 & 60579 \\
Solow residual $S R^{a}$ & 0.0008 & 0.079 & -0.037 & 0.037 & 60579 \\
$\Delta q-\Delta k$ & 0.007 & 0.219 & -0.116 & 0.137 & 60579 \\
$\left(\alpha_{N}+\alpha_{M}-1\right)(\Delta n-\Delta k)$ & 0.0002 & 0.019 & -0.005 & 0.005 & 60579 \\
\hline
\end{tabular}

${ }^{a} S R=\Delta q-\alpha_{N} \Delta n-\alpha_{M} \Delta m-\left(1-\alpha_{N}-\alpha_{M}\right) \Delta k$. 
Table 2

Sector analysis: Estimated sector-level mark-up $\hat{\mu}_{j}$ and workers' bargaining power $\hat{\phi}_{j}$, FE and GMM results

\begin{tabular}{|c|c|c|c|c|c|c|c|c|c|}
\hline \multirow[b]{2}{*}{ Code } & \multirow[b]{2}{*}{$\begin{array}{c}\text { \# Obs. } \\
\text { (\# Firms) }\end{array}$} & \multicolumn{4}{|c|}{ FIRM FIXED EFFECTS } & \multicolumn{4}{|c|}{ GMM } \\
\hline & & $\hat{\beta}_{j}$ & $\hat{\mu}_{j}=\frac{1}{1-\widehat{\beta}_{j}}$ & $\widehat{\gamma}_{j}$ & $\hat{\phi}_{j}=\frac{\widehat{\gamma}_{j}}{1+\widehat{\gamma}_{j}}$ & $\hat{\beta}_{j}$ & $\hat{\mu}_{j}=\frac{1}{1-\widehat{\beta}_{j}}$ & $\widehat{\gamma}_{j}$ & $\hat{\phi}_{j}=\frac{\widehat{\gamma}_{j}}{1+\hat{\gamma}_{j}}$ \\
\hline 15 & $3893(787)$ & $0.195^{* * *}(0.008)$ & $1.242^{* * *}(0.012)$ & $0.670^{* * *}(0.120)$ & $0.401^{* * *}(0.043)$ & $0.198^{* * *}(0.032)$ & $1.247^{* * *}(0.050)$ & $0.350(0.441)$ & $0.259(0.242)$ \\
\hline 17 & $1957(377)$ & $0.178^{* * *}(0.010)$ & $1.216^{* * *}(0.014)$ & $1.137^{* * *}(0.165)$ & $0.532^{* * *}(0.036)$ & $0.211^{* * *}(0.037)$ & $1.267^{* * *}(0.059)$ & $1.679^{* * *}(0.543)$ & $0.627^{* * *}(0.076)$ \\
\hline 18 & $834(192)$ & $0.111^{* * *}(0.012)$ & $1.124^{* * *}(0.015)$ & $0.420^{*}(0.254)$ & $.296^{* * *}(0.126)$ & $0.134^{* * *}(0.027)$ & $1.155^{* * *}(0.036)$ & $0.022(0.711)$ & $0.022(0.681)$ \\
\hline 19 & $432(74)$ & $103^{* * *}(0.019)$ & $1.115^{* * *}(0.023)$ & $0.238(0.371)$ & $.192(0.242)$ & $0.101^{* * *}(0.036)$ & $1.112^{* * *}(0.045)$ & $1.272^{*}(0$ & $0.560^{* * *}(0.132)$ \\
\hline 20 & $948(213)$ & $0.145^{* * *}(0.016)$ & $1.170^{* * *}(0.022)$ & $0.597^{* *}(0.268)$ & $0.374^{* * *}(0.105)$ & $0.076^{* * *}(0.021)$ & $1.082^{* * *}(0.246)$ & $-0.302(1 . \varepsilon$ & $-0.433(3.777)$ \\
\hline 21 & $55(3$ & $197^{* * *}(0.013)$ & $1.246^{* * *}(0.019)$ & $0.841^{* * *}(0.1$ & $.457^{* * *}(0.043)$ & $0.213^{* * *}(0.037)$ & $1.271^{* * *}(0.060)$ & 1.15 & $*(0.059)$ \\
\hline 22 & $4824(112$ & $87^{* * *}(0.007)$ & $1.230^{* * *}(0.011)$ & $0.244^{* * *}(0.075)$ & $0.196^{* * *}(0.048)$ & $0.191^{* * *}(0.035)$ & $1.236^{* * *}(0.053)$ & $0.316(0.2$ & $.166)$ \\
\hline 24 & $4061(781)$ & $0.235^{* * *}(0.009)$ & $1.308^{* * *}(0.015)$ & $0.821^{* * *}(0.104)$ & $0.451^{* * *}(0.031)$ & $0.209^{* * *}(0.038)$ & $1.264^{* * *}(0.051)$ & $1.171^{* *}(0$ & $0.539^{* * *}(0.098)$ \\
\hline 25 & 94( & $0.200^{* * *}(0.009)$ & $1.250^{* * *}(0.014)$ & $0.455^{* * *}(0.107)$ & $.313^{* * *}(0.050)$ & $0.212^{* * *}(0.034)$ & $1.269^{* * *}(0.055)$ & 0.0 & $0.062(0.315)$ \\
\hline 26 & $1607(305)$ & $36^{* * *}(0.016)$ & $1.309^{* * *}(0.027)$ & $0.978^{* * *}(0.174)$ & $0.494^{* * *}(0.044)$ & $0.253^{* * *}(0.056)$ & $1.339^{* * *}(0.100)$ & $0.552(0$ & $0.356^{*}(0.198)$ \\
\hline 27 & $1779(337)$ & $0.186^{* * *}(0.0110)$ & $1.329^{* * *}(0.017)$ & $0.733^{* * *}(0.192)$ & $0.423^{* * *}(0.064)$ & $0.210^{* * *}(0.033)$ & $1.266^{* * *}(0.053)$ & $1.385^{* *}(0$ & $0.581^{* * *}(0.100)$ \\
\hline 28 & $5061(1115)$ & $190^{* * *}(0.007)$ & $1.235^{* * *}(0.011)$ & $0.442^{* * *}(0.109)$ & $0.306^{* * *}(0.053)$ & $* * * \quad(0$. & $1.212^{* * *}(0.050)$ & -0.2 & $0.446)$ \\
\hline 29 & $5417(1101)$ & $0.198^{* * *}(0.006)$ & $1.247^{* * *}(0.010)$ & $0.829^{* * *}(0.100)$ & $0.453^{* * *}(0.030)$ & $0.225^{* * *}(0.031)$ & $1.290^{* * *}(0.052)$ & $0.869^{*}(0.507)$ & $0.465^{* * *}(0.145)$ \\
\hline 30 & $563(142)$ & $0.179^{* * *}(0.018)$ & $1.219^{* * *}(0.026)$ & $0.523^{* * *}(0.202)$ & $0.344^{* * *}(0.087)$ & $0.159^{* * *}(0.037)$ & $1.189^{* * *}(0.052)$ & $0.179(0.251)$ & $0.152(0.181)$ \\
\hline 31 & $2181(475)$ & $0.273^{* * *}(0.012)$ & $1.375^{* * *}(0.023)$ & $1.228^{* * *}(0.147)$ & $0.551^{* * *}(0.030)$ & $0.318^{* * *}(0.043)$ & $1.466^{* * *}(0.092)$ & 1.04 & $0.511^{* * *}(0.108)$ \\
\hline 32 & $1393(325)$ & $0.309^{* * *}(0.015)$ & $1.448^{* * *}(0.032)$ & $1.289^{* * *}(0.211)$ & $0.563^{* * *}(0.040)$ & $0.390^{* * *}(0.041)$ & $1.639^{* * *}(0.110)$ & $1.316^{* * *}(0.467)$ & $0.568^{* * *}(0.087)$ \\
\hline 33 & $2155(478)$ & $0.222^{* * *}(0.012)$ & $1.285^{* * *}(0.019)$ & $0.637^{* * *}(0.148)$ & $0.389^{* * *}(0.055)$ & $0.210^{* * *}(0.033)$ & $1.266^{* * *}(0.053)$ & $0.252(0.488)$ & $0.201(0.311)$ \\
\hline 34 & $1682(320)$ & $0.193^{* * *}(0.012)$ & $1.239^{* * *}(0.019)$ & $0.807^{* * *}(0.223)$ & $0.447^{* * *}(0.068)$ & $0.269^{* * *}(0.026)$ & $1.368^{* * *}(0.049)$ & $1.526^{* * *}(0.486)$ & $0.604^{* * *}(0.076)$ \\
\hline 35 & $847(205)$ & $0.234^{* * *}(0.015)$ & $1.306^{* * *}(0.026)$ & $0.951^{* * *}(0.188)$ & $0.488^{* * *}(0.049)$ & $0.230^{* * *}(0.026)$ & $1.299^{* * *}(0.044)$ & $0.807^{* *}(0.368)$ & $0.447^{* * *}(0.113)$ \\
\hline 36 & $2468(55$ & $0.173^{* * *}(0.009)$ & $1.210^{* * *}(0.013)$ & $0.627^{* * *}(0.136)$ & $0.385^{* * *}(0.051)$ & $0.174^{* * *}(0.031)$ & $1.211^{* * *}(0.045)$ & $0.265(0.414)$ & $0.209(0.259)$ \\
\hline \multicolumn{2}{|c|}{ Sector average } & $0.197(0.012)$ & $1.250(0.018)$ & $0.723(0.172)$ & $0.403(0.065)$ & $0.208(0.044)$ & $1.272(0.068)$ & $0.685(0.517)$ & $0.310(0.378)$ \\
\hline
\end{tabular}

$\overline{S R_{i t}}=\Delta q_{i t}-\alpha_{N_{i t}} \Delta n_{i t}-\alpha_{M_{i t}} \Delta m_{i t}-\left(1-\alpha_{N_{i t}}-\alpha_{M_{i t}}\right) \Delta k_{i t}$

$$
=\beta\left(\Delta q_{i t}-\Delta k_{i t}\right)-\gamma\left(1-\alpha_{N_{i t}}-\alpha_{M_{i t}}\right)\left(\Delta n_{i t}-\Delta k_{i t}\right)+(1-\beta) \Delta \theta_{i t}
$$

Time dummies are included but not reported. FE: robust standard errors in parentheses.

GMM: robust standard errors with finite-sample correction for the two-step covariance matrix (Windmeijer, 2005).

*** Significant at $1 \% ;{ }^{* *}$ Significant at $5 \% ;{ }^{*}$ Significant at $10 \%$. 
Table 3

Correlation between FE and GMM estimates

\begin{tabular}{llllll|lll}
\hline & & & & & & \multicolumn{3}{|c}{ Correlation FE-GMM } \\
\hline & & Mean & Sd. & Min & Max & Unweighted & Weight 1 & Weight 2 \\
\hline$\widehat{\beta}_{j}$ & FE & 0.197 & 0.048 & 0.103 & 0.309 & $0.89^{* * *}$ & $0.85^{* * *}$ & $0.86^{* * *}$ \\
& GMM & 0.208 & 0.069 & 0.076 & 0.390 & & & \\
\hline$\widehat{\gamma}_{j}$ & FE & 0.723 & 0.298 & 0.238 & 1.289 & $0.57^{* * *}$ & $0.72^{* * *}$ & $0.71^{* * *}$ \\
& GMM & 0.685 & 0.611 & -0.302 & 1.679 & & & \\
\hline
\end{tabular}

Weight 1: $\frac{1}{\widehat{\sigma}_{F E}^{2}}$, weight $2: \frac{1}{\widehat{\sigma}_{F E} \widehat{\sigma}_{G M M}}$

Table 4

Variance analysis

\begin{tabular}{|c|c|c|}
\hline & Mark-up $\hat{\mu}_{j s t}$ & Barg. power $\widehat{\phi}_{j s t}$ \\
\hline \multicolumn{3}{|c|}{ PERIOD (ref: 1991-1994) } \\
\hline $1995-1998$ & $\begin{array}{l}-0.053^{* * *} \\
(0.019)\end{array}$ & $\begin{array}{l}-0.120^{* * *} \\
(0.019)\end{array}$ \\
\hline $1999-2003$ & $\begin{array}{l}-0.048^{* *} \\
(0.020)\end{array}$ & $\begin{array}{l}-0.126^{* * *} \\
(0.020)\end{array}$ \\
\hline \multicolumn{3}{|c|}{ SIZE (ref: small firms) } \\
\hline Medium-sized & $\begin{array}{l}0.047^{* * *} \\
(0.012)\end{array}$ & $\begin{array}{l}0.055^{* *} \\
(0.021)\end{array}$ \\
\hline Large & $\begin{array}{l}0.049^{* * *} \\
(0.016)\end{array}$ & $\begin{array}{l}0.029 \\
(0.021)\end{array}$ \\
\hline$\overline{\mathrm{R}^{2}}$ & 0.310 & 0.573 \\
\hline \# Obs. & 179 & 179 \\
\hline \multicolumn{3}{|c|}{ SHARE OF EXPL. VARIANCE } \\
\hline Sector & $73 \%^{* * *}$ & $71 \%{ }^{* * *}$ \\
\hline Period & $11 \% * * *$ & $26 \%{ }^{* * *}$ \\
\hline Size & $16 \%{ }^{* * *}$ & $3 \%^{* *}$ \\
\hline
\end{tabular}

*** Significant at 1\%; ${ }^{* *}$ Significant at $5 \% ;{ }^{*}$ Significant at $10 \%$. 
Table 5

Determinants of estimated price-cost mark-up $\hat{\mu}_{j s p}$

\begin{tabular}{|c|c|c|c|c|c|c|c|}
\hline Variables & $(\mathbf{1})^{a}$ & $(2)^{a}$ & $(3)^{a}$ & $(4)^{a}$ & $(5)^{a}$ & $(6)^{a}$ & $(7)^{b}$ \\
\hline \multirow{2}{*}{ 1995-1998 } & $-0.040^{*}$ & $-0.053^{* *}$ & $-0.054^{* *}$ & & & & $-0.064^{* *}$ \\
\hline & $(0.024)$ & $(0.024)$ & $(0.024)$ & & & & $(0.025)$ \\
\hline \multirow{2}{*}{ 1999-2003 } & -0.023 & -0.021 & -0.019 & & & & $-0.037^{*}$ \\
\hline & $(0.023)$ & $(0.023)$ & $(0.023)$ & & & & $(0.022)$ \\
\hline \multirow{2}{*}{ Medium-sized } & $0.046^{* * *}$ & $0.044^{* * *}$ & & & & & $0.044^{* * *}$ \\
\hline & $(0.012)$ & $(0.012)$ & & & & & $(0.012)$ \\
\hline \multirow{2}{*}{ Large } & $0.050^{* * *}$ & $0.051^{* * *}$ & & & & & $0.051^{* * *}$ \\
\hline & $(0.017)$ & $(0.017)$ & & & & & $(0.017)$ \\
\hline \multirow{2}{*}{$\log (\mathrm{N})$} & & & $0.017^{* * *}$ & $0.017^{* * *}$ & $0.017^{* * *}$ & $0.017^{* * *}$ & \\
\hline & & & $(0.005)$ & $(0.005)$ & $(0.005)$ & $(0.005)$ & \\
\hline \multirow{2}{*}{ VALUCYC } & -0.042 & 0.021 & 0.011 & $-0.308^{* *}$ & $-0.339^{* *}$ & $-0.320^{* *}$ & 0.040 \\
\hline & $(0.210)$ & $(0.205)$ & $(0.200)$ & $(0.143$ & $(0.144)$ & $(0.144)$ & $(0.206)$ \\
\hline \multirow{2}{*}{$\operatorname{lag}($ EXPFIRM) } & -0.064 & -0.102 & -0.123 & -0.117 & -0.122 & -0.117 & -0.137 \\
\hline & $(0.182)$ & $(0.183)$ & $(0.185)$ & $(0.184)$ & $(0.182)$ & $(0.184)$ & $(0.185)$ \\
\hline \multirow{2}{*}{$\operatorname{lag}($ IMPORT) } & -0.278 & & & & & & \\
\hline & $(0.323)$ & & & & & & \\
\hline \multirow{2}{*}{ lag(IMPNORTH) } & & $-1.133^{* * *}$ & $-1.181^{* * *}$ & $-0.877^{* *}$ & $-0.989^{* *}$ & $-0.942^{* *}$ & $-1.372^{* * *}$ \\
\hline & & $(0.376)$ & $(0.371)$ & $(0.353)$ & $(0.379)$ & $(0.398)$ & $(0.386)$ \\
\hline \multirow{2}{*}{ lag(IMPSOUTH) } & & 0.254 & 0.257 & 0.314 & 0.196 & 0.326 & $0.799^{*}$ \\
\hline & & $(0.334)$ & $(0.336)$ & $(0.324)$ & $(0.324)$ & $(0.326)$ & $(0.418)$ \\
\hline \multirow{2}{*}{ lag(R\&DRATIO) } & $4.369^{*}$ & 3.663 & $3.687^{*}$ & 3.659 & 3.578 & 3.420 & 2.561 \\
\hline & $(2.483)$ & $(2.221)$ & $(2.205)$ & $(2.243)$ & $(2.264)$ & $(2.335)$ & $(2.014)$ \\
\hline \multirow{2}{*}{$\operatorname{lag}(\mathrm{PMR})$} & & & & 0.013 & & 0.013 & \\
\hline & & & & $(0.013)$ & & $(0.013)$ & \\
\hline \multirow{2}{*}{$\operatorname{lag}(\mathrm{CAPIT})$} & & & & & -0.007 & & \\
\hline & & & & & $(0.026)$ & & \\
\hline HERF & & & & & & $\begin{array}{l}-0.095 \\
(0.205)\end{array}$ & \\
\hline Sector dummies & YES & YES & YES & YES & YES & YES & YES \\
\hline $\mathbf{R}^{2}$ & 0.321 & 0.357 & 0.351 & 0.336 & 0.332 & 0.332 & 0.358 \\
\hline \#Obs. & 179 & 179 & 179 & 179 & 179 & 179 & 179 \\
\hline
\end{tabular}

Robust standard errors in parentheses. ${ }^{* * *}$ Significant at $1 \% ;{ }^{* *}$ Significant at $5 \%$; ${ }^{*}$ Significant at $10 \%$.

${ }^{a}$ 3-year lags used.

${ }^{b}$ 5-year lags used except for EXPFIRM. For this variable, we are forced to take 3-year lags because of data availability in the first sub-period. 
Table 6

Determinants of the estimated workers' bargaining power $\widehat{\phi}_{j s p}$

\begin{tabular}{|c|c|c|c|c|c|c|c|c|c|c|}
\hline Variables & $(\mathbf{1})^{a}$ & $(2)^{a}$ & $(3)^{a}$ & $(4)^{a}$ & $(5)^{a}$ & $(6)^{a}$ & $(7)^{a}$ & $(8)^{b}$ & $(\mathbf{9})^{b}$ & $(\mathbf{1 0})^{b}$ \\
\hline 1995-1998 & $\begin{array}{l}-0.112^{\text {*** }} \\
(0.020)\end{array}$ & $\begin{array}{l}-0.109^{* * *} \\
(0.020)\end{array}$ & & & & & & $\begin{array}{l}-0.115^{* * *} \\
(0.021)\end{array}$ & & \\
\hline 1999-2003 & $\begin{array}{l}-0.108^{* * *} \\
(0.024)\end{array}$ & $\begin{array}{l}-0.108^{* * *} \\
(0.025)\end{array}$ & & & & & & $\begin{array}{l}0.119^{* * *} \\
(0.026)\end{array}$ & & \\
\hline Medium-sized & $\begin{array}{l}0.049^{* *} \\
(0.022)\end{array}$ & $\begin{array}{l}0.048^{* *} \\
(0.021)\end{array}$ & & & & & & $\begin{array}{l}0.045^{* *} \\
(0.025)\end{array}$ & $\begin{array}{l}0.061^{* * *} \\
(0.025)\end{array}$ & \\
\hline Large & $\begin{array}{l}0.015 \\
(0.025)\end{array}$ & $\begin{array}{l}0.016 \\
(0.024)\end{array}$ & & & & & & $\begin{array}{l}0.011 \\
(0.032)\end{array}$ & $\begin{array}{l}0.036 \\
(0.032)\end{array}$ & \\
\hline $\log (N)$ & & & $\begin{array}{l}-0.005 \\
(0.006) \\
\end{array}$ & $\begin{array}{c}-0.004 \\
(0.006) \\
\end{array}$ & $\begin{array}{l}0.0005 \\
(0.006) \\
\end{array}$ & $\begin{array}{l}-0.002 \\
(0.006) \\
\end{array}$ & $\begin{array}{l}-0.002 \\
(0.006) \\
\end{array}$ & & & $\begin{array}{l}0.001 \\
(0.006)\end{array}$ \\
\hline $\operatorname{lag}($ EXPFIRM) & $\begin{array}{l}0.284 \\
(0.184)\end{array}$ & $\begin{array}{l}0.297 \\
(0.194)\end{array}$ & $\begin{array}{l}0.378^{*} \\
(0.206)\end{array}$ & $\begin{array}{l}0.370^{*} \\
(0.208)\end{array}$ & $\begin{array}{l}0.235 \\
(0.206)\end{array}$ & $\begin{array}{l}0.348^{*} \\
(0.210)\end{array}$ & $\begin{array}{l}0.344 \\
(0.210)\end{array}$ & $\begin{array}{l}0.343^{*} \\
(0.198)\end{array}$ & $\begin{array}{l}0.200 \\
(0.205)\end{array}$ & $\begin{array}{l}0.256 \\
(0.212)\end{array}$ \\
\hline lag(IMPORT) & $\begin{array}{l}-0.376^{* *} \\
(0.179)\end{array}$ & & & & & & & & & \\
\hline lag(IMPNORTH) & & $\begin{array}{l}-0.850^{* *} \\
(0.352)\end{array}$ & $\begin{array}{l}-0.655^{*} \\
(0.383)\end{array}$ & $\begin{array}{c}-0.665^{*} \\
(0.393)\end{array}$ & $\begin{array}{l}-1.539^{* * *} \\
(0.328)\end{array}$ & $\begin{array}{l}-0.817^{*} \\
(0.415)\end{array}$ & $\begin{array}{l}-0.836^{* *} \\
(0.417)\end{array}$ & $\begin{array}{l}-0.476 \\
(0.510)\end{array}$ & $\begin{array}{l}-0.935^{*} \\
(0.522)\end{array}$ & $\begin{array}{l}-1.020^{* *} \\
(0.508)\end{array}$ \\
\hline $\operatorname{lag}($ IMPSOUTH) & & $\begin{array}{l}0.211 \\
(0.288)\end{array}$ & $\begin{array}{l}0.327 \\
(0.299)\end{array}$ & $\begin{array}{l}0.303 \\
(0.314)\end{array}$ & $\begin{array}{l}-0.416 \\
(0.347)\end{array}$ & $\begin{array}{l}0.140 \\
(0.369)\end{array}$ & $\begin{array}{l}0.117 \\
(0.373)\end{array}$ & $\begin{array}{l}0.189 \\
(0.396)\end{array}$ & $\begin{array}{l}-0.768 \\
(0.476)\end{array}$ & $\begin{array}{l}-0.733 \\
(0.543)\end{array}$ \\
\hline $\operatorname{lag}($ R\&DRATIO) & $\begin{array}{l}2.041 \\
(2.098)\end{array}$ & $\begin{array}{l}-1.688 \\
(2.079)\end{array}$ & $\begin{array}{l}-1.305 \\
(2.111)\end{array}$ & $\begin{array}{l}-1.359 \\
(2.160)\end{array}$ & $\begin{array}{l}-2.040 \\
(2.033)\end{array}$ & $\begin{array}{l}-1.612 \\
(2.313)\end{array}$ & $\begin{array}{l}-1.653 \\
(2.326)\end{array}$ & $\begin{array}{l}-0.107 \\
(1.967)\end{array}$ & $\begin{array}{l}-1.517 \\
(2.298)\end{array}$ & $\begin{array}{l}-1.481 \\
(2.288)\end{array}$ \\
\hline $\operatorname{lag}(\mathrm{PMR})$ & & & $\begin{array}{l}0.072^{* * *} \\
(0.014)\end{array}$ & & & & & & & \\
\hline $\operatorname{lag}($ UNIONDENS) & & & & $\begin{array}{l}1.384^{* * *} \\
(0.289)\end{array}$ & & & & & & \\
\hline lag(UNEMPRATE) & & & & & $\begin{array}{l}-2.281^{* * *} \\
(0.691)\end{array}$ & & & & & \\
\hline REPLRATE & & & & & & $\begin{array}{l}3.795^{* * *} \\
(1.058)\end{array}$ & & & & \\
\hline $\operatorname{lag}(\mathrm{CAPIT})$ & & & & & & & $\begin{array}{l}-0.115^{\text {*** }} \\
(0.033)\end{array}$ & & & \\
\hline HERF & & $\begin{array}{l}0.274^{*} \\
(0.156)\end{array}$ & $\begin{array}{l}0.390^{* *} \\
(0.173)\end{array}$ & $\begin{array}{l}0.408^{* *} \\
(0.179)\end{array}$ & $\begin{array}{l}0.292 \\
(0.186)\end{array}$ & $\begin{array}{c}0.449^{* *} \\
(0.197)\end{array}$ & $\begin{array}{l}0.451^{* *} \\
(0.199)\end{array}$ & $\begin{array}{c}0.321^{* *} \\
(0.155)\end{array}$ & $\begin{array}{l}0.501^{* *} \\
(0.215)\end{array}$ & $\begin{array}{l}0.536^{* *} \\
(0.215)\end{array}$ \\
\hline Sector dummies & YES & YES & YES & YES & YES & YES & YES & YES & YES & YES \\
\hline $\mathbf{R}^{2}$ & 0.575 & 0.581 & 0.553 & 0.546 & 0.524 & 0.521 & 0.519 & 0.573 & 0.492 & 0.473 \\
\hline \#Obs. & 179 & 179 & 179 & 179 & 179 & 179 & 179 & 179 & 179 & 179 \\
\hline
\end{tabular}

Robust standard errors in parentheses. ${ }^{* * *}$ Significant at $1 \%$; ${ }^{* *}$ Significant at $5 \%$; ${ }^{*}$ Significant at $10 \%$.

${ }^{a}$ 3-year lags used.

${ }^{b}$ 5-year lags used except for EX PFIRM. For this variable, we are forced to take 3-year lags because of data availability in the first subperiod. 